\title{
Social Entrepreneurship and Social Venture in Nepal, Case of Martyrs Memorial Park (Sahid Smarak), Hetauda, Nepal
}

\author{
Yam Bahadur Silwal (PhD) \\ Lecturer \\ Faculty of Management, Makawanpur Multiple Campus \\ Email: yamsilwal@gmail.com
}

\begin{abstract}
This study primarily tried to find out social entrepreneurship practices in Nepal, though this is an young phenomena for scholarly in Nepal. Study followed exploratory case type and selected Martyrs Memorial Park (Sahid Smarak) as a case so that it is a qualitative research. Social entrepreneurship is phenomena about utilization of creative idea of individuals for the society and social benefits through entrepreneurship and entrepreneurial venture creation. Martyrs Memorial Park (Sahid Smarak) is a social venture situated in Hetauda, Bagmati province, Nepal established by social and political personalities. This venture is found as a good practice of social entrepreneurship that generate revenue for the society, providing employment opportunities, utilizing resources, paying tax, contributing to uplift tourism, giving recognition of the area and members of the executive committee and council members as well. This venture became a model for others and many are trying to implement this in another part of the country. Social entrepreneurship process model found which started from social or political person with entrepreneurship intention that converted into entrepreneurial behavior and realize the social venture. Then economic outputs bring transformation in the society and generate social entrepreneurs' personality enrichment.
\end{abstract}

Key Words: Social entrepreneurship, Social entrepreneurial intention, Social entrepreneurial behavior, Social venture, Social transformation, and Personality enrichment

\section{Introduction}

Entrepreneurship is defined as starting and managing a business for the purpose of growth, income and personal satisfaction - contributes importantly to employment, economic growth and innovation in developed and developing countries around the globe (Hisrich. R., 2007). The individual perspective proposes that people's individual characteristics, interests and personality traits exert a strong influence on whether one will become an entrepreneur (Rauch, 2007). The economic perspective suggests that macroeconomic factors, such as regional economic diversity 
or population growth, determine the rate to which people engage in entrepreneurship (Reynolds, 1995). The socialization or social learning perspective suggests that parents act as role models and thus influence their children's career plans (Scherer, 1980). Family business owners may also influence the career paths of their successors by being more or less generative (Hannes Zacher, 2011). Unlike commercial entrepreneurs, whose economic aim may have a social impact and contribute to economic development through creating jobs, services and valuable goods (Austin J. S.-S., 2006).

Social Entrepreneurship (SE) defined as the application of entrepreneurial ideas to address a social issue, enhance ecological balance, and ensure sustainable development that targeted to achieve social goals with presence of the elements of entrepreneurship and reinvested the social venture economic gains to solve social problems (Sohel \& Shamsuddoha, 2019). It is the process of collective efforts to innovate social value for social benefits throughout the social venture creation (Doyle Corner \& Ho, 2010). In spite of its infancy, it is obvious that social enterprise sector is increasingly being recognized as a significant economic contributor for the nation (Kadir \& Sarif, 2016). Success of social entrepreneurial ventures might have the potentiality to solve growing disparity of incomes and increasing degradation of the environment. It has been considered as essential economic engines for development in emerging economies but there is insufficient research on important dimensions of these ventures (Sarason, Yuthas, \& Nguyen, Social Entrepreneurial Ventures in Vietnam: An Ideographic Lens, 2018).

Social Entrepreneurship often triggered by a transformative value conviction to serve a concern rooted social entrepreneurs' upbringing (Waddock, 2016). Many social entrepreneurs have experienced traumatic or troubled childhood and channel these experiences to offer pragmatic social solutions (Barendsen, 2004). Social entrepreneurs possess strong values and capacities, and are able to seize opportunities to create social value in an innovative fashion (Rahdari, 2016).

Social problems seem to be vague issues in worldwide like unemployment, increasing socio- economic inequalities, ageing population, climate change, health and education (Rob Lubberin, 2018). Social entrepreneurship as having the following three components: (1) identifying a stable but inherently unjust equilibrium that 
causes the exclusion, marginalization, or suffering of a segment of humanity that lacks the financial means or political clout to achieve any transformative benefit on its own; (2) identifying an opportunity in this unjust equilibrium, developing a social value proposition, and bringing to bear inspiration, creativity, direct action, courage, and fortitude, thereby challenging the stable state's hegemony; and (3) forging a new, stable equilibrium that releases trapped potential or alleviates the suffering of the targeted group, and through imitation and the creation of a stable ecosystem around the new equilibrium ensuring a better future for the targeted group and even society at large (Osberg, Standford Social Innovation Reviw, 2007).

Social entrepreneurship is exercised where some person or group aim at creating social value, either exclusively or at least in some prominent way, show a capacity to recognize and take advantage of opportunities to create that value envision, employ innovation, ranging from outright invention to adapting someone else's novelty, in creating and/or distributing social value, willing to accept an aboveaverage degree of risk in creating and disseminating social value, and unusually resourceful in being relatively undaunted by scarce assets in pursuing their social venture (Ines Alegre, 2017). Social organizations such as Ashoka and the Soll foundation have created platforms for social entrepreneurship to stimulate their problem-solving role in society (Sassmannshausen, 2016). The process of social entrepreneurship can be viewed as a process of problem solving. The goal of the enterprise can be seen as finding a solution to a social problem (Arikboga, 2015).

A study carried out by Oguzhan Irengun and Sebnem Arikboga (2015) that personality traits such as neuroticism, openness, extraversion, agreeableness, and consciousness are influential for social entrepreneurial intentions. Social vision, use of resources and financial return succeed social enterprises. Intentions to set up a social venture develop from perceptions of desirability, which are effected by emotional and cognitive attitudes, and from perceptions of feasibility, which are instigated by enabling factors such as self-efficacy and social support (Mair \& Noboa, 2003).

Personal initiative theory was tested in a study carried out in Uganda empirically investigating personal initiative in predicting social entrepreneurial venture creation. Studies have been ensured that individuals need to take personal initiative to create social entrepreneurial ventures in developing countries (Nsereko, 
Balunywa, Munene, Orobia, \& Muhammed, 2018). One study verified and fitted model SE for national sustainable development promotion by the public sector for Iran. The impact of social life expectancy increase on livability, social welfare increase on social justice, social technology use on social assets of community organizations, also social innovation timing on social assets of community organizations, compatibility with national and international regulations on balanced consumption of natural resources and finally regulations on pollution reduction (Forouharfar, Rowshan, \& Salarzehi, 2019). Social entrepreneurial ventures should be autonomy, belonging, connectivity, diversity and emergence followed by the systems of system theory was examined and tested with USA based nonprofit organization MedShare International by scholars (Robb \& Gandhi, 2015).

Personal initiative has a number of dimensions which include innovation, resourcefulness, creativity, dedication, vision, resilience, and optimism among others (Johnmark, Munene, \& Balunywa, 2016).

Proactiveness is an opportunity seeking, forward-looking perspective involving introducing new products or services ahead competition. Proactive persons will always have a behavior of starting a new business. It acts in anticipation of the future demand to create change and shape environment (Hughes \& Morgan, 2006).

Innovation is a motion towards new products, method of production and transportation, services, markets, organization (Schumpeter, Capitalism, Socialism and Democracy, 1994). Innovative entrepreneurs recognize and discover social opportunities that create something new. The aim of innovation is to bring a positive change (Austin, Stevenson, \& Wei-Skillern, 2006).

Social entrepreneurial behavior is a set of decisions about which opportunity to pursue, how to raise funds, what social organizational form to take, where to obtain further information and support, who to employ on the start-up team, and so on. It is used interchangeably with social entrepreneurial venture creation too (Bird \& Schjoedt, 2009). Social entrepreneurs could be gathered social support from social network for social services and recognition.

Nepalese culture is very collectivistic. They believe in togetherness and happy to live in interdependence community. People of Nepal are very much interested to 
make contribution for the society (https://culturalatlas.sbs.com.au/, 2020). There have been operating many traditional social institutions since hundreds years in Nepal for social services on the basis of religious and cultural belief system. Beside this, any social institutions have been established and operating not for profit with economic transactions, generating revenues, and providing employment opportunity. On the basis of revisiting the existing scholarly studies, author proposed following conceptual map for social entrepreneurship development or social entrepreneurial venture creation.

As social entrepreneurship is young concept, further more in case of Nepal, there are many social institutions have been operating in various perspectives and contexts. Whether SE is practiced or not, and if it is then how is it practicing, are the main issues of this study. The objective of this study is to compare social entrepreneurship concept with social enterprises have been created and prospects to sustain in Nepal.

\section{Materials and Method Used}

The purpose of study is to connect and compare SE concept with social venture in Nepal. This is an exploratory case study followed qualitative approach. The study is bounded within social and not for profit institution that generating income, providing employment opportunity, promotes economic activities and personality involved with innovativeness. Under those mentioned boundaries, Sahid Smarak (Martyrs Memorial Park), a social enterprise was selected as a case. The study is based on primary data and that collected from the institutional archival records, financial report of last six years, and in-depth interview with key informant like chairperson, other board members, staffs and local residential people all together thirty persons. Data presented in the form of mostly narrative and content analysis was done.

\section{Result and Discussion}

For the purpose of illustration of mentioned objective of the study, on the basis of archival documents observed about the institution, an overview generated as bellow;

\section{Overview of Sahid Smarak (Martyrs Memorial Park)}


Initially, after democracy reestablishment in 1990, some of the local level politicians conceptualized martyrs memorial garden to be established and they selected one of the desolation area situated in Hetauda Municipality ward number 11 and had plantation on behalf of pay gratitude towards those who sacrificed their lives during the peoples' movement for democracy. Its geographic area is about 20 hectors land. Later on, they felt need to sustain such area and formed an institution after three years. Martyrs Memorial Park named in Nepali language Sahid Smarak Bikas Samiti was officially established with the registration in 1994 AD (2051 BS) under the social institution registration act 1977 AD ( 2034 BS) of Nepal. There was provision of executive committee along with thirteen members and fifty one council members. But right now there are thirty members executive committee, ten member advisory committee, three member financial committee, three member monitoring committee within 139 council members as per provision of its own statute.

Numbers of visitors have crossed five lacs per year. Visitors are both foreigners as well as domestics. It is perceived one of the best attractive tourism destination in the region. Within the park premises, there are various spots found as follows;

All spots are purposefully developed. Some spots are to honour martyrs, some for studies, some for fun and entertainment, for pilgrim, recreation, workshop, seminar, and for tourists etc. There are found 28 various spots such as Martyrs Statue (Sahid Smmarak), Martyrs Memorial Pillar (Sahid Smriti Stambh), Center for Martyrs Study and Research (Sahid Adhyayan Tatha Anusandhan Kendra), Center for Martyrs Study and Research (Sahid Adhyayan Tatha Anusandhan Kendra), Democratic Park (Prajatantrik Park), Madan Memorial and Garden (Madan Smarak Tatha Vatika), Thaha Statue (Thaha Stamva), Silver Jubilee Statue (Rajat Jayanti Pratima), Native Gate of Martyrs Memorial (Sahid Sarak Ko Maulik Prabesh Dwar), Belly Bridge with New Technology (Naya Pravidhi Ko Jholunge Pool), Tourism Information Center (Paryatan Suchana Kendra), Water Fountain (Phohora Sahit Ko Park), Children Entertainment Center (Bal Manoranjan Kendra), Nursery (Narsari), Marriage Spot (Bibaha Mandap), Swimming Pool (Poudi Pokhari), Small Zoo, Picnic Shades, Horse Riding, Photo Studio, Truss Bridge, Residential Seminar Hall, Ethnicity Museum, Devi Temple, Statue of Lord Buddha, and so on. These spots are 
regularly maintained with keeping neat and clean. Greenery and ecology have been given topmost priority by executive committee of the park.

Institutional Structure and Operation Flow of Sahid Smarak (Martyrs Memorial Park)

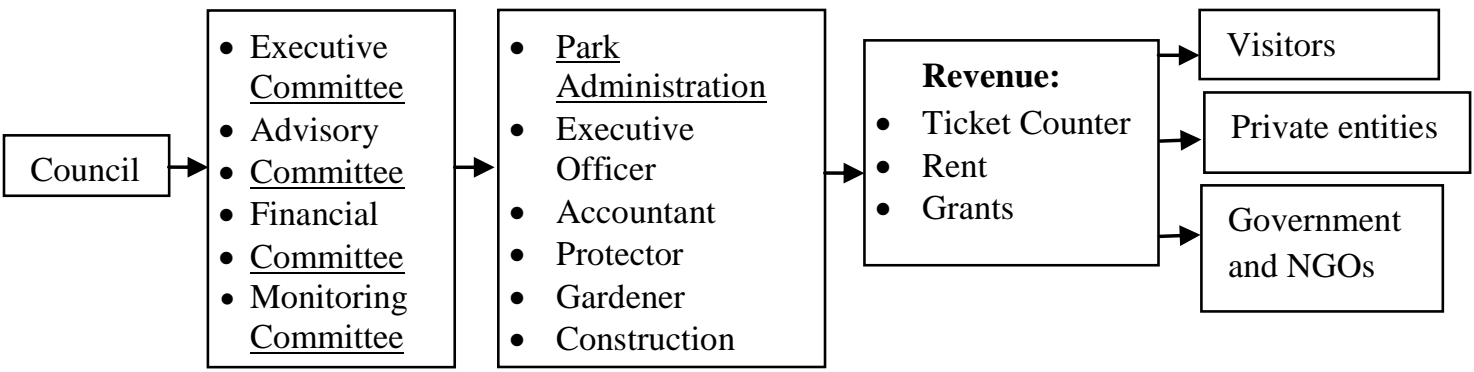

Figure-1: Institutional Structure

Currently 139 social and political persons are as permanent members formed a council. Council is guided by registered statute of the martyrs memorial park. General Assembly of the council elects martyrs memorial park development committee as executive body that operates institution. General Assembly also elects financial committee and monitoring committee. Regular meeting of the executive committee form an advisory committee on the basis of requirements. Executive committee delegates authority to administration for handling day to day operations of the park. There are provision of chief administrator, account section and other general staffs. This administration operates the park with performed every day scheduled work. Revenue collects from visitors is main source of the venture and monthly basis amount also receipt as rent from private small entrepreneurs who run hotels, restaurants, stalls, fun park etc. Another source of revenue specially for infrastructure development are various Nepalese government agencies of local, provincial and federal government and non-government institutions existing in the society. In this way, this functional structure of the park is operating. 


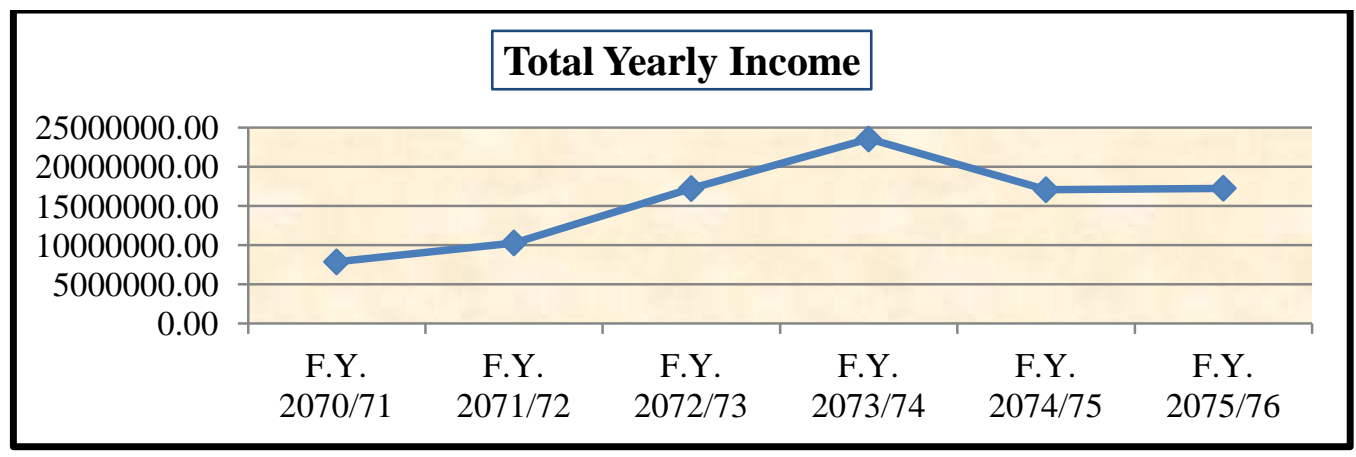

Figure 2: Yearly Income of the park

Source: Audited Financial Reports of Park Development Committee

Income of the park is in increasing trend since last six years. Income of last two years is a little bit in steady stage. This income has recovered all expenses of the park except total capital expenditures that has invested for the development of new infrastructures as new spots. A large part of the capital investment is collected as grants from various government agencies and other institutions through social network of leaders of the park.

This institution is being one of the good tax payer social venture in this area. It has provided job opportunity for 31 persons as regular staffs in various positions and around 10 person part time staffs in daily basis. There are also 35 small stores operating by small entrepreneurs and they pay rent to the park in monthly basis. Around five lacs visitors are visited yearly and this number is in increasing trend and the park has become tourist destination. Visitors coming from various locations inside and outside the country opened business opportunities for the hotels, restaurants, transporters, local sellers etc. So, this is providing direct and indirect employment as well as business opportunities and is contributing to resolve unemployment problem in the country to some extent (Rana, 2020).

In-depth interview was done with executive committee chairperson, members and executive officer. Founder chairperson since starting to till is currently Honorable Dormani Poudel, Chief Minister of Bagmati province of Nepal, he was mayor of the Hetauda municipality at that time when the park established, had focused on initially he and his colleagues devoted to martyrs and they begin as a small park for the memorized and honored all martyrs sacrificed their life for nation and democracy. Then gradually they begin to think about sustainability of the park. He began to thinking how to generate regular revenue to maintain and sustain. Then he found idea 
and began to charge entrance ticket fee from the visitors. Numbers of visitors have been gradually increased and his committee encouraged to give newness for visitors continuously and started to versioned the park as a large venture in future. He has been regularly tried to get grants from government and non-non government agencies to develop new infrastructures and also able to increase internal revenue generation. Societies have also fully supported this initiative. Now it is seemed as a model social enterprise of nation. Leading this institution gave me very significant recognition and now politically I am in good position he apologized. Other members of the committee Mr. Anant Prasad Paudel, Mr. Bishwa Raj Baniya, Mr. Badri Prasad Lamsal, Mrs. Sumitra Kafle, Mrs. Bishnu Ojha were interviewed. Their common responses were they support to the chairperson's vision to implementation as much as possible. They were also trying always to utilize their network to promote and develop the park. Ten persons from local residents were also interviewed and asked them about change they perceived in terms of economic, social, cultural, institutional, and learning aspects after the park establishment.

Political personality defined with having traits such as openness to experience, conscientiousness, extraversion, agreeableness, and emotional stability (Ribeiro \& Borba, 2016). He/she might be associated with political ideology and political party. Social personality considered as helping motives to society in various specific problems (Staub, 1974). Political personality or social personality converted into social entrepreneurial personality to address social problems. Here Honorable Dormani Poudel, Chief Minister of Bagmati province of Nepal, founder of the park is considered as political personality and other many members associated with this institution are social persons also. Content analysis is presented in the table bellow that shows the respondents views;

Question asked to the respondents about person and personality of social entrepreneurship and result is presented as content table;

Table1: Social entrepreneurial intention

\begin{tabular}{|r|l|r|r|}
\hline S.N. & Social entrepreneurial intention & Frequency of response & Rank \\
\hline 1 & Vision & 30 & 1 \\
\hline 2 & Motivation & 29 & 2 \\
\hline
\end{tabular}




\begin{tabular}{|r|l|r|r|}
3 & Identity & 27 & 3 \\
\hline 4 & Trait & 26 & 4 \\
\hline
\end{tabular}

Political and social person having intention with social services can be as social entrepreneur. Such person should have vision to solve social problem through entrepreneurship and should be committed and self-motivated towards vision. Social entrepreneurship embedded strong desire to achieve social identity within person and it needed entrepreneurial traits.

Table 2: Social entrepreneurial behavior

\begin{tabular}{|r|l|r|r|}
\hline S.N. & Social entrepreneurial behavior & Frequency of response & Rank \\
\hline 1 & Proactiveness & 29 & 1 \\
\hline 2 & Innovativeness & 28 & 2 \\
\hline 3 & Personal initiatives & 26 & 3 \\
\hline 4 & Risk taking & 25 & 4 \\
5 & Skill & 24 & 5 \\
\hline
\end{tabular}

Social entrepreneurship intention reflected into the behavior of person as a social entrepreneur. Act in advance or one step ahead than others, identifying newness in terms of product, process, materials, market and organization is most crucial for social entrepreneurship. Implementation of thoughts into the action as personal initiation with taking risk to venture establishment by social entrepreneurs are important step. It also needs managerial skills to handle venture as well.

Table 3: Outcomes of social venture

\begin{tabular}{|r|l|r|r|}
\hline S.N. & Outcomes of social venture & Frequency of response & Rank \\
\hline 1 & Value creation & 30 & 1 \\
\hline 2 & New products/services & 29 & 2 \\
\hline 3 & Process & 28 & 3 \\
\hline 4 & Employment & 27 & 4 \\
\hline
\end{tabular}


IRJMMC Vol. 1 Issue $1 \quad$ (March, 2020) ISSN 2717-4999 (Online) 2717-4980 (Print)

\begin{tabular}{|r|l|r|r|}
5 & Asset & 26 & 5 \\
\hline 6 & Revenue & 25 & 6 \\
7 & Growth & 24 & 7 \\
\hline
\end{tabular}

Successfully operation of social venture generate certain economic outputs such as creation of value, new items like products or services, new process, employment opportunity, wealth, revenue and economic growth. 
Table 4: Social transformation

\begin{tabular}{|r|l|r|r|}
\hline S.N. & Social transformation & Frequency of response & Rank \\
\hline 1 & Role and position & 29 & 1 \\
\hline 2 & Social relation & 28 & 2 \\
\hline 3 & Culture and custom & 25 & 3 \\
\hline 4 & Economy and learning & 23 & 4 \\
\hline 5 & Social perspective & 22 & 5 \\
\hline
\end{tabular}

Outcomes of social venture bring many changes and transformation in the society. Society got various benefits directly and indirectly from the social venture and changes are visibly seen in role and position of people in catchment area of venture, social relation among the people and society, new culture and custom, economic growth and income, learning about social venture and business and social context and perspective.

Table 5: Personality enrichment

\begin{tabular}{|r|l|r|r|}
\hline S.N. & Personality enrichment & Frequency of response & \multicolumn{1}{|l|}{ Rank } \\
\hline 1 & Social recognition & 30 & 1 \\
\hline 2 & Social network & 28 & 2 \\
\hline 3 & Prestige and status & 26 & 3 \\
\hline 4 & Social support & 25 & 4 \\
\hline 5 & Power & 23 & 5 \\
\hline
\end{tabular}

Social entrepreneurs could be enabled to enrich personality in the society through successfully operation of social venture. Result presented in above table shows that recognition in society, social networks, prestige and status of social entrepreneurs are increasing. Getting support from various social sectors for social entrepreneurship and it became one of the significant sources of social and political power. 


\section{Process model of social entrepreneurship}

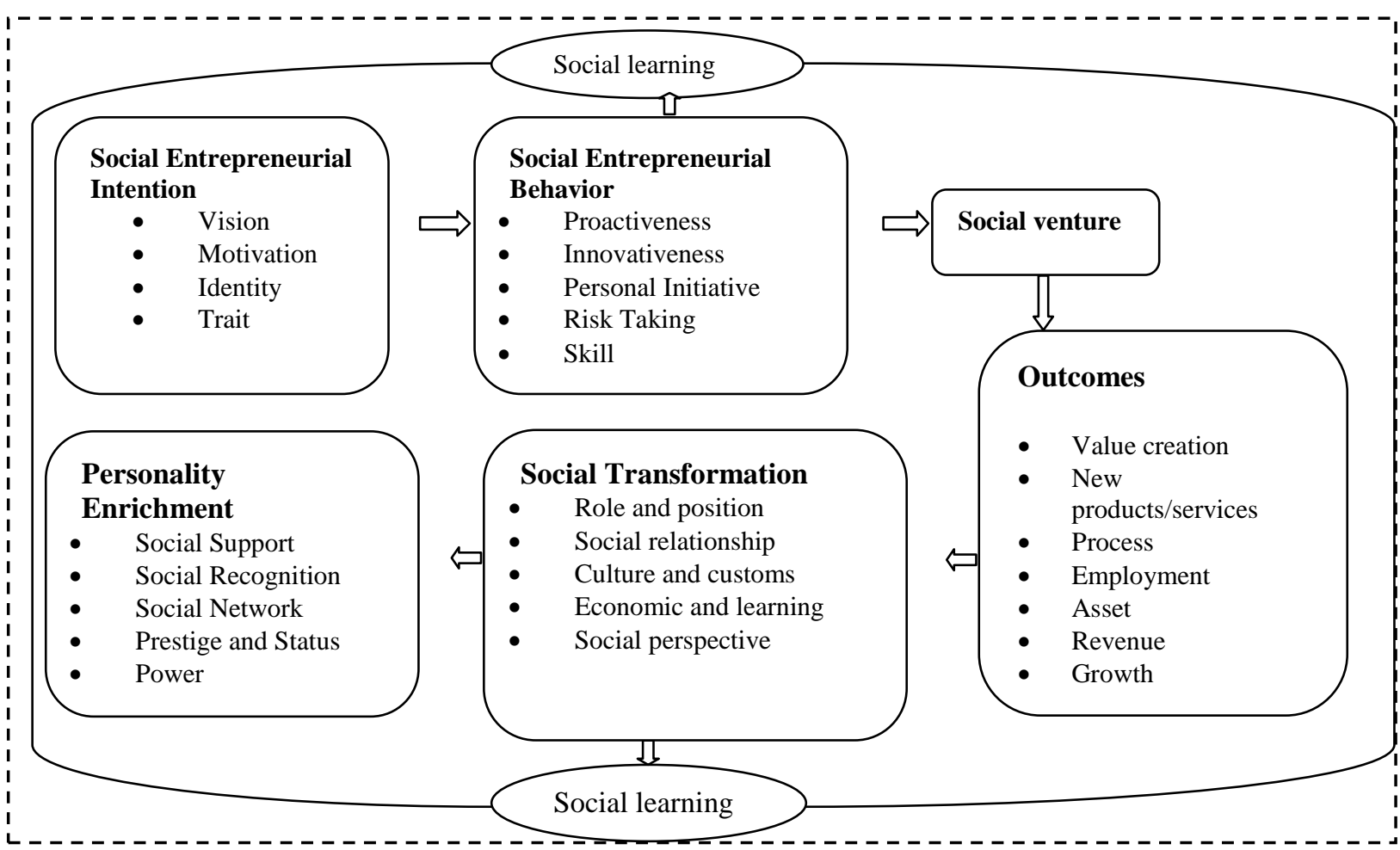

Figure 3: Process model of social entrepreneurship

Figure of social entrepreneurship process model presented above shows that a social worker/political person with social entrepreneurial intention behave entrepreneurial behavior to resolve social problems or issues and establishes and operates a venture. Successful operation of social venture generates specific outcomes which bring transformations in society that develop valuable personality of social entrepreneur. Viewing and interacting with this process, many people have learned social entrepreneurship and encouraged towards social entrepreneurial intention.

\section{Conclusion and Recommendation}

Social entrepreneurship is application of entrepreneurial ability for the social benefit through creation of social venture. In Nepal, there have been practicing social entrepreneurship in many social field. Among them martyrs memorial park, Hetauda, Bagmati province, Nepal is a pioneer social venture as a tourists destination that generating income, providing employment opportunities directly and indirectly, society getting benefited in various aspects, and contributing to nation through tax paying and tourism development. This practice of social entrepreneurship is considered as model venture and many other social and political leaders are trying to 
implement such model in many part of the country. Social entrepreneurship can be developed through the process as social or political persons having entrepreneurial intention converted into entrepreneurial behavior and established social venture. The social venture produces certain economic outputs that generates social transformations or changes and gives personality enhancement of social entrepreneur.

The institutional infrastructure, management and controlling mechanism should me make more updated of the park. The study can be further carried out social, economical, and cultural aspects of the park. Further more studies to be carried out social entrepreneurial venture as characteristics of system of systems, complexity theory and system of systems risk management approach for social entrepreneurial venture in Nepal.

\section{References}

Arikboga, O. I. (2015). The Effect of Personality Traits on Social Entrepreneurship Intentions: A Field Research. World Conference on Technology, Innovation and Entrepreneurship (pp. 1186-1195). Istanbul: Procedia- Social Behavioral Sciences.

Austin, J. S.-S. (2006). Social and Commercial Entrepreneurship: Same, Different, or Both? Entrepreneurship Theory and Practice, 1-22.

Austin, J., Stevenson, H., \& Wei-Skillern, J. (2006, January 1). Social and commercial entrepreneurship: same, different, or both? Entrepreneurship Theory and Practice, 30(1), 1-22. doi:https://doi.org/10.1111/j.1540-6520.2006.00107.x

Barendsen, L. \&. (2004). Is the social entrepreneur a new type of leader? Leader to Leader, 43-50.

Bird, B., \& Schjoedt, L. (2009). Understanding the entrepreneurial mind: Opening the black box (1 ed.). (A. L. Carsrud, Ed.) New York: Springer-Verlag New York. doi:https://doi.org/10.1007/978-1-4419-0443-0

Doyle Corner, P., \& Ho, M. (2010, July). How Opportunities Develop in Social Entrepreneurship. ET\&P, 635-659. doi:10.1111/j.1540-6520.2010.00382.x

Forouharfar, A., Rowshan, S. A., \& Salarzehi, H. (2019, September 22). The Relationship between Social Entrepreneurship and Sustainable Development from the Social Experts' Points of View. Journal of Environmental Education and Sustainable Development, 7(4), 69-82. doi:10.30473/EE.2019.6059

Hannes Zacher, A. S. (2011). Stepping into my shoes: generative as a mediator of the relationship between business owners' age and family succession. Cambridge Journal, 15.

Hisrich. R., L.-F. J. (2007). Entrepreneurship research and practice: a call to action for psychology. American Psychologist, 62(6), 575-89. 
IRJMMC Vol. 1 Issue $1 \quad$ (March, 2020) ISSN 2717-4999 (Online) 2717-4980 (Print)

https://culturalatlas.sbs.com.au/. (2020). Retrieved March 2, 2020, from Cultural Atlas: https://culturalatlas.sbs.com.au/nepalese-culture/nepalese-culture-core-concepts

Hughes, M., \& Morgan, R. E. (2006, June 9). Deconstructing the relationship between entrepreneurial orientation and business performance at the embryonic stage of firm growth. Industrial Marketing Management, 651-661. doi:10.1016/j.indmarman.2006.04.003

Ines Alegre, S. K.-M. (2017). Organized Chaos: Mapping the Definitions of Social Entrepreneurship. Journal of Social Entrepreneurship, 248-264.

Johnmark, D. R., Munene, J. C., \& Balunywa, W. (2016, April 8). Robustness of personal initiative in moderating entrepreneurial intentions and actions of disabled students. Cogent Business \& Manageent. doi: https://doi.org/10.1080/23311975.2016.1169575

Kadir, M. A., \& Sarif, S. M. (2016). Social Entrepreneurship, Social Entrepreneur and Social Enterprise: A Review of Concepts, Definitions and Development in Malaysia. Journal of Emerging Economies and Islaic Research, 4(2), 1-16. Retrieved February 5, 2020, from www.jeeir.com

Mair, J., \& Noboa, E. (2003, September). Social Entreprenruship: How Intentions to Create a Social Enterprise Get Formed. IESE Business School, University of Navarra.

Nsereko, I., Balunywa, W., Munene, J., Orobia, L., \& Muhammed, N. (2018, February 28). Personal initiative: Its power in social entrepreneurial venture creation. doi:https://doi.org/10.1080/23311975.2018.1443686

Osberg, R. L. (Spring 2007). Retrieved February 26, 2019, from Standford Social Innovation Reviw: https://ssir.org/articles/entry/social_entrepreneurship_the_case_for_definition

Rahdari, A. S. (2016). Achieving sustainability through Schumpeterian social entrepreneurship: The role of social enterprises. Journal of Cleaner Production, 347360.

Rana, R. (2020, January 23). Silver Jubilee of Martyrs Memorial Park (Sahid Smarak Ko Pachchis Basant). Martyrs Memorial Park Sovenier 2020 BS (Sahid Smarak Darpan 2076). Hetauda, Bagmati, Nepal: Martyrs Memorial Park Development Committee .

Rauch, A. a. (2007). Let's put the person back into entrepreneurship research: a meta-analysis on the relationship between business owners' personality traits, business creation, and success. European Journal of Work and Organizational Psychology, 16(4), 353-85.

Reynolds, P. M. (1995). Explaining regional variation in business births and deaths- U.S. Small Business Economics, 7(5), 389-407.

Rob Lubberin, V. B. (2018). Innovation for Society: Towards a Typology of Developing Innovations by Social Entrepreneurs. Journal of Social Entrepreneurship, 9, 52-78.

Robb, C., \& Gandhi, S. J. (2015, December 10). Social Entrepreneurial Ventures: On the Edge of Chaos? doi:10.1515/erj-2015-0030 
Sarason, Y., Yuthas, K., \& Nguyen, L. (2018). Social Entrepreneurial Ventures in Vietnam: An Ideographic Lens. Dalat University Journal of Science, 8(1), 83-112. Retrieved from https://www.researchgate.net/publication/326305914

Sassmannshausen, S. a. (2016). The Scientometrics of Social Entrepreneurship and Its Establishment as an Academic Field. Journal of Small Business Management, 1-23.

Scherer, R. F. (1980). Role model performance effects on development of entrepreneurial career preference. Entrepreneurship Theory and Practice, 13(3), 53-71.

Schumpeter, J. A. (1994). Capitalism, Socialism and Democracy. (R. Swedberg, Ed.) George Allen \& Unwin (Publishers) Ltd 1976.

Sohel, D. M., \& Shamsuddoha, D. M. (2019). The Essence of 'Social' in Social Entrepreneurship. Society \& Sustainability, 1(1), 38-45. Retrieved February 6, 2020, from https://www.researchgate.net/publication/338395652

Waddock, S. \&. (2016). Visionaries and Wayfinders: Deliberate and Emergent Pathways to Vision in Social Entrepreneurship. Journal of Business Ethics, 719-734. 